\title{
Strengthening the Importance of the Citizen in Territorial Government: A Necessity for Development and Modernization of Albania - A Libertarian Approach to Territorial Issues
}

\section{Gentian Kaprata}

European University of Tirana

\begin{abstract}
Albania is a developing country that has embarked on the path of transition from a society of monist governance and centralized planning economy to a society of liberal democracy with free market economy 30 years ago. It is not moving at the pace it intended in the early 1990s, because of the etatist mentality of the country's political elite, but often also of experts in certain sectors. This has happened in these years also in the sector of territorial planning and development, where etatist understandings have impeded the empowerment of citizens in the processes of drafting territorial planning and development decision-making. This has led to development taking place in two different ways, on one hand governments have attempted to control development by forcing citizens to interact with the territory according to the rigid rules imposed by the government, and on the other hand the citizens have carried out construction developments in a fragmented manner, and without any harmony between each other and the obligations of government. In this paper we aimed to build another approach for future development in an Albania aiming at integration into the European Union. This path should be development based on previously adopted territorial planning instruments, drawn up in democratic and parliamentary processes. Governance must understand and accept the new and different role it played 30 years ago in territorial development issues, and recognize citizens as co-actors in the processes of drafting territorial and urban planning instruments.
\end{abstract}

Keywords: individual freedom, government power, classical liberal, citizen empowerment, citizen involvement in planning processes.

\section{Introduction}

In all western countries of liberal democracy, but also in other countries with not the same level of democracy as the former, the level of citizen empowerment in territorial governance has been increased (sectors of territorial development of government), involving the citizen more and more in the process of drafting territorial planning and decision-making for urban development. This is a decades-long tradition for European countries and the United States of America, but in the last two decades countries like those in Latin America and China have been experimenting in this direction (Boonstra and Boelens, 2011). We have begun this article with a brief introduction to the historical contradiction between individual freedom and government authority from its inception. How the individual in the beginnings fought to 
expand his power in the face of political authority, and to expand governing activities where his thought and opinion were valued and included in government decision making (Mill, 2005). Further, we have introduced the two types of coordination of society's actions; one, the 'police state technique', as a coercion of society and its compulsion by political power to follow the rules unilaterally set by political power itself; and the other, the 'technique of liberal democracy', where the co-ordination of individuals' actions in society resulted from the free will of individuals to cooperate voluntarily (Friedman, 2005). The Albanian society, which has spent 46 years in a one-party Communist Party regime that decided on everything and everyone, knows the first technique very well, but the path taken 30 years ago requires knowing and experimenting as much as possible with the second technique (Biberaj, 2000; Lami, 2013). The article follows with a presentation of the good practices of western countries of liberal democracy, but also of countries with more fragile and similar democracy to Albania, in terms of empowering the citizen in territorial governance, through involvement in the processes of designing territorial planning instruments, interested parties and citizens affected by the developments provided for in these instruments. As well as a valuable theoretical contribution to citizen participation in governance, it presented and argued the eight levels of citizen participation in the processes of drafting territorial planning instruments and in the governance decision-making procedures for urban administration (Arnstein, 1969). Further, in this article, we briefly present the importance that European Union institutions attach, through policy documents - at the level of technical expertise, of local authorities, national authorities, and European Union institutions - to the involvement of citizens in the processes. territorial planning and decision making in the urban sector (CNU, 1996; UNECE, 2008; EU, 2004, 2010). The article goes on to explain the level of citizen representation - as an interested party, or individual citizens - in territorial planning processes, according to the level of governance that has its own functions as that type of planning (central or local). In the following, the article briefly presents the current practices of citizen involvement in concrete planning processes developed in Albania. Furthermore, some conclusions are provided on the most important legal but also cultural challenges that Albanian governments in the future must face in order to empower the citizen in relation to the governing authority, through the involvement of interested parties and citizens in the drafting process of territorial planning instruments, and other benefits emanating from this liberal and democratic approach. The article is concluded with some recommendations for the Assembly of the Republic of Albania, central government and local government in the future Albania.

\section{The historical contradiction between the freedom of the individual and the power of government}

The contradictory relationship between individual freedoms and government power is one of the most distinctive features of social evolution since the earliest periods of human history, especially those of Greece, Rome, and England. In antiquity this conflictual relationship was established between citizens or some classes of citizens, on the one hand, and the government on the other. As Mill would define it, "Freedom was to defend against the tyranny of political rulers. Rulers were conceived (with the exception of some of the popular [democratic] governments of Greece) as a necessary antagonistic position with the people they ruled" (Mill, 2005 , p. 5-6). Without going into the contextualization of history, at this period it is about the rule of the leader of the tribe or caste who had gained their power either as an inheritance 
from his successor or through the conquest of new territories that were not under previous control from the predecessor whom they had inherited the power to rule.

In this formative context, the rulers did not exercise their power for the benefit of the citizens governing them, and at the same time the people ruled by them did not dare or wish to discuss the superiority of their rulers. The role of the oppressor by the rulers over their subjects was considered and accepted by them, on the one hand as indispensable and, on the other, very dangerous, as it could serve the subjects to protect them from external enemies or it could harm them if used against their freedoms. As Mill would explain this contradiction metaphorically "To prevent the weakest members of the community from falling prey to countless predators, it was necessary for the stronger predator [the ruler] to be authorized to protect them. But as the king of predators [the ruler] would rule over the prey [the subjects] no less than the little predators, it was necessary to maintain a permanent defensive attitude against his beak and claws" (Mill, 2005, p. 6). In this context, the individuals of antiquity considered and valued their freedom.

To remain at Mill's approach, which emphasized "as long as the people were content to fight one enemy with another and be ruled by a master, on the condition of being more or less guaranteed of his tyranny, they did not bring their aspirations [for freedom] beyond this point" (Mill, 2005, p. 7), we can say that guaranteeing this situation required a guarantee from the ruler. It therefore required the provision of certain immunities, the breach of which would be regarded as a breach of duty by the ruler and at the same time create the right of the subjects and justify their resistance or rebellion against the ruler. These immunities were considered freedom or political rights (Mill, 2005). As a second step, but also as a later tool towards freedom, came constitutional obligations. According to them, it became indispensable, the need of their preference by the community or some kind of community representative body directly, for some of the most important acts of government and the exercise of governing power.

Thus, we can say that the first elements of representative democracy and citizen involvement in governance were born, but they were also anaemic and infant stages (Mill, 2005). Moreover, as Mill would point out: "In most European countries the ruling power was to some extent subject to the first restrictive modes [immunities called freedom or political rights]. But this was not the case for the latter [constitutional obligations], and their attainment, or when they were already somewhat possessed, their complete attainment, became everywhere the chief aim of the lovers of liberty" (Mill, 2005, p. 6).

Further in time, as the issue of individual freedoms and political rights progressed, there came a time when people no longer saw the ruler as a natural need and accepted the fact that their rulers were an independent, and often opposed power with their interests (Mill, 2005). Here began the dynamics of the transition of government from the rule of a permanent king, a power which was hereditary, and the citizens needed to accept what they had, into an interim government. For the people it was better for the governing elite of the state to be people who were concessionary in exercising power, or were their delegates and revocable from office, with the consent of the people. In this way, the people were regarded as the only ones who had the complete assurance that governments would not use power to the detriment of the citizens.

This substituted, as Mill would have pointed out, "earlier attempts to limit the power of the rulers" (Mill, 2005, p. 7), thus, to empower the citizen in government. However, if the 
government were elected by the citizens then the value of the concept of limiting the power of the ruler whose interests were contrary to those of the people would be lost. The point was to argue that while it was required, as Mill would point out, "that rulers should be aligned with the people, that their interest and will should be the interest and will of the nation. The nation did not need to be protected by its own will. He was not afraid of becoming his own tyrant. If the rulers are accountable to him and are immediately replaceable by him, then he can entrust them with the power which he himself dictates how to use" (Mill, 2005, p. 7).

\section{Ways of coordinating human activity in society}

By the time the democratic republics began to be installed in many countries of the Western world and in this sense the government elected by the people was broken into the new subject to be observed and criticized by the people who were enamoured with the freedom of the individual and his involvement in governing affairs. As Mill would point out, "it was already thought that locutions such as 'self-government' and 'people's power over the people themselves' did not express the real state of affairs. The 'people' who exercise power are not always the same as those over whom they exercise power. The 'self-government' that is spoken of is not the rule of each one of himself, but of each one from all the rest." (Mill, 2005, p. 7).

Thus two innovations arose, first, the fear of majority tyranny, which was considered and still considered frightening because it operates through acts of public authorities (Mill, 1859), and liberalism which would essentially protect the freedom of the individual and empower of his political will in government, as Friedman would put it, "As liberals [classical], we consider freedom of the individual, or of the family, as our ultimate goal in judging social adjustments" (Friedman, 2005, p. 13). , or, as Spencer would point out, "[classical] liberals usually backed individual freedom against state coercion" (Spencer, 2005, p. 19).

According to classical liberals, there are only two ways to coordinate human activity, the first is the central direction from the governing authority through coercion, and the second is the voluntary cooperation of individuals. The former are techniques of the police, military, autocratic and totalitarian state, and rely on the thesis that, as Friedman would put it, "purpose justifies the means" (Friedman, 2005, p. 25).

So undemocratic governments justify their actions, in the sense that Friedman gives them, the means of coercion against the individual they use, on the grounds that the high purpose they have set for themselves for the good of society justifies the means of violence they use to force individuals to accept what is dictated to them. This thesis in itself is not logical, because it means that the purpose in question is not the ultimate goal, on the contrary the ultimate goal is to use the suitable means (Friedman, 2005).

The second ways of coordinating human activity are techniques of liberal democracy and free markets (Friedman, 2005). As Friedman would point out, "For the [classical] liberal, the appropriate means are free discussion and voluntary cooperation, which implies that any form of coercion is inappropriate." (Friedman, 2005, p. 25).

This is the essence of libertarianism, free and responsible citizens, gather voluntarily, discuss issues that concern them and agree on how these problems can be improved or eliminated. The typical area of human freedom encompasses three aspects: first, the absolute freedom of thought and opinion in all areas, which are inseparable from freedom of expression without any restriction of such thoughts and opinions; second, the freedom of weaving his own life plan according to the character and as we please with the only restriction that this plan does 
not harm another individual; third, the individual's freedom to befriend and associate with other individuals (Mill, 2005, pp. 18-19).

\section{Levels of civic involvement in the processes of drafting territorial planning instruments}

Collaborative methods of planning and those of civic engagement in planning processes are an issue of fundamental importance in spatial planning in the world today. Western and liberal democracy states, but also others that do not have a long tradition of democracy, have evolved methods of involving citizens in planning processes with the aim of strengthening its role in governance and decision-making. Interactive, collaborative approaches as methods for involving citizens in governance and participatory planning have been widely introduced in the United States, Italy, the United Kingdom, Belgium, the Scandinavian countries and even in countries such as China and Brazil (Boonstra and Boelens, 2011).

The Netherlands is where these practices began to be attempted, as Boonstra and Boelens would emphasize, "some attempts have been made since the 1960s to involve citizens from the outset in the spatial development process, and interaction has been advocated between government agencies, entrepreneurs. and civil organizations, or, between public, business and civil stakeholders, as a multi-participant approach to planning" (Boonstra and Boelens, 2011, p. 101). Involvement of citizens in planning processes includes several areas of spatial strategies, territorial planning and administration and management of issues, problems and urban imbalances. Two are the basic ways through which civic engagement is targeted in territorial planning processes, the first is to increase active citizen participation, and the second is the division of responsibilities for urban and territorial affairs between governing institutions and civic communities (Boonstra and Boelens, 2011).

To remain on the Boonstra and Boelens approach, they would point out that "Citizen participation in governing decision making has a long history of at least 45 years [55 years] in Dutch planning. It was first introduced by the 'New Left' of the Dutch Social Democrats in the mid-1960s. It aimed to be an emancipating and democratizing movements that was included in the US (as a result of the demonstrations for Vietnam), France (student revolt), Germany (the Dutschkes march through the Institutions) and post-war riots in other Western countries " (Boonstra and Boelens, 2011, p. 107). New left-wing politicians in the Netherlands, aiming to improve the political system from the inside, went against the existing program of the Social Democratic Party, where they were embroiled in the argument that "it was no longer in line with the ideas and dreams of the new generation "(Boonstra and Boelens, 2011, p. 109). Thus came the first level of participatory planning called 'Public Hearings' applied in the 1970s, when the 'New Left' took over the party leadership, and many of its members came to power as governors, and more later also as ministers.

This was an important step for empowering the citizen in government, but far from the realistic need, because as Boonstra and Boelens would point out, "it merely introduced in practice only the real possibility of citizens to criticize and respond to spatial proposals made by governing agencies. " (Boonstra and Boelens, 2011, p. 110). As the practice of 'Public Hearings' was soon regarded as ineffective, new ideas emerged and were implemented in Dutch practices of planning processes aimed at empowering the citizen. Thus came the second level of citizen empowerment in territorial governance we call 'Collaborative Planning', implying cooperation in public-private sector planning processes, as Boonstra and Boelens would argue, "local or regional governments, even nationals choose to cooperate with key business stakeholders (key project developers or investors) and also with civil society in order to develop 
a realistic plan in which each interested party has their own responsibilities" (Boonstra and Boelens, 2011, p. 114).

The third level of empowerment of the citizen's role in government decision-making has been widespread lately in countries with fragile democracies such as Latin America and China. We call it 'Budgeting Initiatives' and means financing through public budgets, or co-financing public and private budgets for projects initiated by citizen communities (Boonstra and Boelens, 2011). However, it is theorized that civic participation in spatial planning processes is not productive and is thought to have produced disappointing results. According to Boonstra and Boelens, it is argued that "participation in spatial planning remains controlled by public governments and that these public governments do not appear to be very adaptable to initiatives arising from the dynamics of civil society itself" (Boonstra and Boelens, 2011, p. 99). In their paper 'Self-organization in urban development: towards a new perspective in spatial planning', they propose another model of citizen empowerment in territorial governance by presenting 'the notion of self-organization, referring to the initiatives that emerge from civil society itself, through community-based autonomous citizen networks, outside government control, which participates in the development of 'urban textures'"' (Boonstra and Boelens, 2011, p. 99).

A valuable theoretical contribution to citizen participation in government was made in 1969 by Sherry Arnstein through her paper 'A Ladder Of Citizen Participation', published in the scientific journal "Journal of the American Planning Association". In this paper she presented and argued that there are eight levels of citizen participation in the processes of drafting territorial planning instruments and in the procedures of regulating decision making on urban administration. Arntein called them levels of participation and presented them in the form of a scaling typology of civic participation, in which each individual scale corresponds to a certain level of citizen power in designing a governance plan, program, or project. The eight pedestrians (i.e. levels) of the scale of civic participation are, manipulation, therapy, information, consultation, flattery, cooperation, delegation of power and civic control (Arnstein, 1969). Many countries use the Arnstein scale to improve the level of citizen involvement in local development processes.

\section{Citizen involvement in planning processes as a European principle}

The emphasis of planning that includes and empowers the citizen is placed on all documents with political approaches of world and European planners, including, but not limited to, the Congress on New Urbanism in their document 'The Charter of New Urbanism', in which it would be stated "We are committed to stabilizing the relationship between the art of building and making communities, through the participation of communities in planning and design" (CNU, 1996).

In addition to the technical and scientific dimension, countries of liberal democracies attach great importance to the involvement of citizens in territorial and spatial planning and decision-making processes. The United Nations Economic Commission for Europe would give it very specific importance, especially for transition countries in its document 'Spatial Planning: Key Development Instruments and Effective Governance, with Special Reference to Transition Countries'. As highlighted in this report, it urged developing and transition countries "to increase broad participation, improve community involvement and build support for sustainable planning policies and programs" (UNECE, 2008, p. 12). 
In the same vein, the European Union, in the 'Urban Acquis' document, adopted at the Ministerial for Territorial Cohesion, which took place in Rotterdam in 2004, would emphasize that one of the mechanisms for successful urban policy should be considered the concept of' "Leadership from above to be balanced by empowering communities from below". Among other things, the 'Urban Acquis' document stated that "Citizen participation should be based on a dialogue with experts to stimulate citizenship in the urban environment" as a way to prove in practice the importance of citizen involvement in governance (EU, 2004).

During the last decade many documents highlighting the importance of civic engagement in territorial planning processes have been agreed at various political levels, to name only the two most important as' Spatial Planning; Key Instrument for Development and Effective Governance with Special Reference to Countries in Transition' of the United Nations Economic Commission for Europe (UNECE, 2008), and the 'Territorial Agenda 2020, towards a Comprehensive, Smart and Sustainable Europe of Different Regions ', agreed at the Ministerial Informal of the Ministries responsible for Spatial Planning and Territorial Development on 19 May 2011 in Godollo, Hungary (EU, 2010). These documents and others we touched upon were the beginnings of a long process which will continue in the future, especially in developing countries such as Albania, which are indispensable in taking steps in this very important direction of democracy and development.

\section{Albanian practices of citizen involvement in transition planning processes}

The territorial governance of the transitional years did not have a political aim of involving stakeholders and citizens in the processes of drafting national strategies on national level issues (Aliaj, 2008; Fuga, 2012). They have not understood their new role in matters of territorial planning and development, throughout the transition to democracy, as the IHS Alumni et al., presents us. "The state is no longer the only decision maker. Today's urban reality is the product of all the interference of particular people, companies and organizations living and working in the city" (IHS Alumni et al., 1998, p. 3). Territorial governments in transitional Albanian have not understood the importance of empowering the citizen in the process of drafting territorial planning instruments, as Fuga would point out, "involves [the citizen] at a higher level of magnitude among public opinion, political decision-making and power" (Fuga, 2012, p. 75).

This has produced the exclusion of stakeholders and citizens affected by the proposed development by implying that citizen knowledge and opinions on their needs and desires are not important and not valid. Mill would counter this etatist concept, "Judgment is given to people to use. Because, can people be told that they should not use judgment at all because they can use it wrong? To prohibit [authority] what they think is harmful does not mean that it excludes them from error, but that [authority] is carrying out the task that belongs to them [the citizens]" (Mill, 2005, p. 25). But in contrast, the view and opinion of stakeholders and citizens are decisive in the processes of drafting territorial planning instruments because the city is built by people and for people (IHS Alumniet al., 1998; Aliaj, 2008; Imami et al., 2008) and their exclusion brings a planning that is not valid in practice. And as a logical breakdown of territory, it develops into two plans, first the plan that the etatist government imposes, and second the fragmented and atomized plans of each individual and group of individuals representing their particular interests (Aliaj, 2008). That is to say, development is not based on an instrument accepted and recognized by all parties working on the territory. 
Involving interested parties and their citizens or groups affected by development is a democratic and inclusive exercise carried out at both levels of government, as UNECE would highlight: "Participation in the planning process is greatly improved where co-operation meetings bring together different interested parties. and at different levels of planning (strategic or local)" (UNECE, 2008, p. 37). But also, as IHS Alumni et al., would point out, "Participation can be of different forms" (IHS Alumni et al., 1998, p. 42). The involvement of interested parties, such as government or civil society organizations, organizations of experts in specific fields of knowledge or science, as well as of private enterprises in different development sectors, in national-level planning has been positively appreciated by international institutions, as we can in particular reference UNECE, which would guide "It [participation in the planning process] can also be useful at strategic levels, which include representatives of organizations" (UNECE, 2008, p. 37). But interested parties and citizen participation, as we shall see below, is decisive at the local level of drafting local territorial planning instruments.

For the territorial development of the Albanian Parliament four laws were adopted in the period 1993-2014: law 7693/1993 'On Urbanism' (Official Journal, 1993); law 8405/1998 'On Urban Planning' (QBZ, 2010); Law 10119/2009 'On Territorial Planning and Development' (QBZ, 2019); law no. 107/2014 'On Territory Planning and Development' (QBZ, 2019). These laws have undergone numerous and frequent changes, where it is worth noting that Law 8405/1998 'On Urban Planning' was amended ten times, and Law 10119/2009 'On Territorial Planning and Development' changed several months after the adoption of the Law, prior to the entry into force with full force, by Law No. 10 258, dated 25.3.2010 'On some additions and amendments to Law no.10119, dated 23.4.2009, 'On Territorial Planning'. Although 'hyperlegislation', as Spencer would define the frequent rearranging and changes of legislation (Spencer, 2005), characterized the transition governance in the field of territorial development, it failed to provide the appropriate role to the interested parties and citizenry, in the processes of drafting territorial planning instruments, according to the governing level (HIS Alumni et al., 1998; Aliaj, 2008; Imami et al., 2008; Fuga, 2012).

Without going into the analysis of the legislative text or mentioning of certain articles of laws, it can be said that due to the obligations of the European Union institutions, the concepts of stakeholder and citizens involvement in the planning processes have been introduced in the Albanian legislation. This has been a progressive process, starting with a minimalist element in the law of 1998, to reach an almost acceptable level in the provisions of the law of 2014, as a result of the process of approximation of the legislation with that of the EU. Governing practices, however, prove the opposite, as the processes of drafting local plans have not been open to stakeholders or citizens affected by planned developments (HIS Alumni et al., 1998; Aliaj, 2008; Imami et al., 2008; Fuga, 2012). Contrary to what UNECE would instruct, when emphasizing "Participatory practice works best at the local community level where stakeholders are clear about the constraints and open spaces for decision making" (UNECE, 2008, p. 37).

As Aliaj, reflecting on the United Nations Human Development Report in 2006, would emphasize, "cities must continue to democratize the decision-making of their governments in order to make them more responsive and reactive to citizens" (Aliaj, 2008, p. 90). In contrast, the fourth phase territorial governance, which covered the years 2013-2020, undertook a program to draft general local plans of the 61 municipalities of the Republic. This program has been going on for years and until now 38 Local Government Units have a legally approved planning instrument, while the rest is in the process of drafting or approving this instrument (AKPT, 2015-2020). It is clear that this action, albeit driven by the central government's 
positive desire to equip each local government unit with territorial planning instruments, is an action with a "paternalistic approach" (Friedman, 2005) that undermines local autonomy of local government. But most importantly, for this part of the paper, by concentrating the project on the National Territorial Planning Agency, which is an institution subordinate to the Prime Minister, it removed this autonomy from the citizens of the cities for which each of these instruments is being drafted.

To understand this, it is sufficient to observe the process of drafting the Local General Plan of the Municipality of Tirana. This general territorial instrument was designed by the studio of an Italian architect with the assistance of a group of Municipality specialists, in a process closed to interested parties and affected by the developments envisaged therein as UNECE teaches us "In the early stages of designing a strategy or spatial plan, before planning authorities have decided on a particular solution, it is an advantage to include and engage a wide range of interested parties in discussing issues and in the formulation of proposals. (UNECE, 2008, p. 37). The only interested party engagement process that sector law recognizes as 'Public Hearing' was a single meeting, to present the documents and maps that made up this planning tool to City Council members who are direct representatives of citizens in the 'City Assembly' and a number of local urban and architecture experts who were selected according to the political preference of central government, Tirana Municipality or central government leaders (TCHA, 2016).

This meeting, considered a 'Public Hearing', took place in a one-sided format, with only the political authority of the Municipality or the private studio contacted by the central government to draft the instrument having the right to engage in a discussion. In the meantime, as the leader of the largest opposition group in 'City Assembly', Olli stressed the few invited guests to ask questions or make proposals were generally previously selected by the governing authority (TCHA, 2016). Moreover, as the leader of the other opposition group in 'City Assembly', Brahimllari presented, none of the few suggestions, controlled by the state authority, were considered or reflected in the final product of the planning instrument (Vizion Plus, 2016). Evaluated on the Arnstein scale, although the legal designation of this process corresponds to its fourth step, 'consultation' (Arnstein, 1969), this process was a mix between the first three steps of citizen participation, manipulation, therapy, information.

\section{Conclusions}

Territorial governance (the governing sector dealing with territorial issues), although Albania has been aiming for 30 years to move away from socialist modes of development based on central planning, to move towards development based on an inclusive free market economy, has not been introduced in the legislation and in governing and administrative practices that have this social goal. Involving citizens and interested parties in the processes of designing spatial, territorial and urban planning instruments is one of the most productive methods to empower the citizen in governance decision-making, even according to the institutions of the European Union and other liberal democracy countries. Although the sovereign's stated political intent has been clear: to accelerate integration into the European Union by adopting its principles, and to follow the guidelines given to member states or in the integration processes towards it, and in particular good practices that come from its member countries; yet it seems that the Albanian transition governments have not followed this path required by the sovereign. 
The insufficiency of the three levels of its application so far, as presented earlier in this paper, to give the voice that the citizen deserves in governance matters should lead us in two directions. First, let's look for better ways and models whereby the citizen's opinion is fully incorporated and widely considered by planning instruments and governance decisionmaking, and secondly, let's try to implement those European and Western good practices, even in countries that do not have a democratic tradition like Albania.

Citizens' empowerment must be developed at both levels of government, in civic engagement, according to the planning instruments they design and adopt, and in line with their scope. At national (central) level it can be implemented in the form of interested parties' participation (mainly non-governmental or entrepreneurial organizations, in those sectors covered by the planning instrument), in the processes of drafting territorial development strategies. But what best represents the intention to empower the citizen is his involvement in local territorial planning processes. In these processes the citizen can understand, touch and express his opinion directly on the issues that concern him, or the community which he belongs to. Albania demands a profound legal reform and in particular cultural changes on the issues of territorial planning processes. They should be open to incorporating the view and opinion of interested parties and citizens affected by proposed developments in those planning instruments.

In particular, local planning processes where issues that are dealt with most directly by the citizen and affect them directly should be turned into an agenda of interested parties and citizen deliberations, according to specific topics to be devised and made public. The doors of the City Council meeting room should be open to include all social organizations on various topics, such as heritage, economic, cultural, environment, health, art and sports. All university science departments and city intellectuals should be drawn into the thematic debates. And in parallel, the municipal administration acting as the moderator of the deliberations, the provider of official information and data, as the representative of the interests of minority and non-involved groups, as the technical secretariat that protocols all agreements reached in the deliberations, turning them into either maps or written materials.

Local territorial planning instruments should be regarded as a celebration of the city, with the aim of achieving a spiritual and cultural regeneration of the citizen, community and society.

We need to escape the etatist and concentrative mentalities to open up to the processes of deliberative democracy. Albania's transition from a society of centralization and concentration of decision-making and power should open the processes of planning and decision-making for territorial developments to the thinking of the citizen. Albania needs to move away from 'paternalistic' approaches to governance and considering governing authority as 'upper owner' and place the citizen and his opinion at the centre of planning for future development and in the perspective of the city. We need to move away from the etatist mentality of concentrating the power of knowledge, arguing that citizens do not know and cannot have opinions as valuable as the people of administration or bureaucrats of government.

The city has to be made by the citizens and for the citizens and this is the fundamental reason that at the heart of cities' development perspectives must be the opinion, needs and desires of the citizens. The situation of Albanian cities, with a multitude of problems and urban imbalances, proves this in the Albanian practice of urbanization and urban redevelopment in the transition years. This contradiction has arisen since we, on the one hand, have agreed to 
enter liberal democracy and a free market economy, but on the other hand we do not understand that governance has a different role from the previous one in urban affairs.

Citizen empowerment through involvement in planning processes also brings other benefits. First, social benefits, because civic engagement will contribute strongly to the social coherence of a fragmented society, such as the local Albanian community, due to large migratory movements in the transition years. Citizen participation and inclusion improves social conditions in two ways: through empowerment in governance decision making, as we touched upon earlier; and by empowering them to communicate their need, desire, opinion and point of view, which can serve every aspect of social life. For the Albanian society, after a long period of denial of free thought in communism, this communication enhancement practice is well worth it. Secondly environmental and urban benefits, because the involvement of citizens in planning processes, enhances a 'sense of belonging' of citizens to their environments, very necessary for Albanian society because as a consequence of the communist regime, they find it difficult to believe that ' common property' "is their property. The third benefit is political, because engaging citizens in discussions of needs, deficiencies, problems and imbalances makes them aware of the real possibilities of governance to meet their needs; but also for governments to understand the real needs of citizens, from the way citizens view them, and to narrow the gap between them as much as possible. This beneficial aspect, too, is very important to the post-communist Albanian society, which often views governance as a thing completely separate from itself.

\section{Recommendations}

In this context, we recommend to the Parliament of the Republic of Albania to ask the Council of Ministers or through its internal mechanisms to draft a new legal basis for territorial planning, with particular emphasis being given to comprehensive planning. In this new and necessary legislation, the processes of drafting planning instruments should be transformed into democratic and constitutional processes through the involvement of interested parties, such as governmental and non-governmental organizations, organizations and expert associations of different professions and enterprises of various development sectors; as well as community groups and other citizens affected by the potential development proposed by these territorial planning instruments. Involvement by the interested an affected parties of the potential development should be considered according to the level of governance and the level of territorial planning instruments.

Interested parties, such as governmental and non-governmental organizations, organizations and expert associations of different professions and entreprises in different sectors of development, but not only these, should be involved in the processes of drafting strategic and national level planning instruments. However, this does not mean that the community, and groups of citizens and citizens, should be excluded from the process of drafting national instruments.

Communities and citizen groups and citizens should be particularly involved in the process of drafting national territorial planning instruments. However, this does not mean that other interested parties, such as governmental and non-governmental organizations, organizations and expert associations of different professions and enterprises in different sectors of development, should be excluded from local planning processes. 
I recommend to the central government to seriously consider the dimension of interested parties and citizen involvement in the processes of drafting territorial planning instruments and to reflect this concept clearly and exhaustively in the provisions of a new draft law on territorial planning and development. I also recommend that, from the process of drafting strategic and national-level instruments throughout its governance, to broadly practice the wide involvement of interested parties, including, but not limited to, governmental and nongovernmental organizations, organizations and associations of experts of different professions and enterprises in different sectors of development. The central government should consider and include in their planning products their thoughts and opinions as they express their specific needs, wants and capabilities.

I recommend to the local government to give a special and very important place to civic engagement in its planning practices. Local government should value civic engagement, not only as a legal obligation, but also as a practical necessity for planning and territorial development instruments to be complete, and have realistic opportunities to implement them fully in line with how they are drafted. Local government should turn the processes of drafting local territorial instruments under their administration, as a celebration of democracy for their city, where all interested parties, professional organizations, communities and citizen groups, even individual citizens, interested or affected by potential development, to be participatory.

\section{Bibliography}

[1] Agjensia Kombëtare e Planifikimit të Territorit, [AKPT], (2015-2020), 'Plane të Përgjithshme Vendore' http://planifikimi.gov.al/index.php?id=732

[2] Aliaj, B., (2008), 'Misteri i Gjashtë', shtëpia botuese Botime Afrojdit, Tiranë

[3] Arnstein, Sherry R., (1969) 'A Ladder Of Citizen Participation', Journal of the American Planning Association, Vol. 35, No. 4, 216-224

[4] Biberaj, E., (2000), 'Shqipëria në Tranzicion; Rruga e vështirë drejt demokracisë', Tiranë: botimet Ora

[5] Boonstra B. and Boelens L., (2011), 'Self-organization in urban development: towards a new perspective on spatial planning', Urban Research \& Practice, Vol. 4, No. 2, July, 99-122

[6] Congress for the New Urbanism, [CNU], (1996), 'Charter of the New Urbanism' , Vancouver, Canada https://ëëë.cnu.org/ëho-ëe-are/charter-neë-urbanism

[7] European Commission, [EC], (1994), 'Charter of European Cities \& Towns Towards Sustainability, Aalborg

Denmark https://sustainablecities.eu/fileadmin/repository/Aalborg_Charter/Aalborg_Charte r_English.pdf

[8] European Commission, [EC], (2005), 'Acquis Urban; Using Cities' Best Practises for European Cohesion Policy Common Declaration of URBAN cities and players at the European Conference "URBAN Future" on June 8th and 9th, 2005 in Saarbrücken (Germany) https://ec.europa.eu/regional_policy/archive/newsroom/document/pdf/saarbruck en_urban_en.pdf

[9] European Council of Town Planners, [ECTP], (2003) 'The New Charter of Athens 2003; Vision for Cities in the 21st century', Lisbon http://ëëë.ceuectp.eu/images/stories/doënload/charter2003.pdf 
[10] European Union, [EU], (2007), 'LEIPZIG CHARTER on Sustainable European Cities, Leipzig https://ec.europa.eu/regional_policy/archive/themes/urban/leipzig_charter.pdf

[11] European Union, [EU], (2004) , 'Urban Acquis' Ministerial Meeting on Territorial Cohesion on 29 November 2004 in Rotterdam https://ec.europa.eu/commission/presscorner/detail/en/MEM0_04_278

[12] Friedman, M., (2005), 'Kapitalizmi dhe Liria', përkthim nga Adri Nurellari, Tiranë: Shtëpia Botuese IPLS dhe Dita,

[13] Fuga, A., (2012), 'Rënia e Qytetit', Tiranë: Shtëpia Botuese Papirus,

[14] IHS Alumni, IHS, Co-Plan, (1998), 'Qyteti i ndërtuar nga njerëzit; Ide për të menaxhuar realitetin urban në Shqipëri', Tiranë: Shtëpia Botuese Eurorilindja,

[15] Imami, A., Dhamo, S., Derraj, E., Kulluri., Lelaj, O., dhe Aliaj, B., (2008), 'Hapësira qytetare drejt fundit të tranzicionit ?!, Këndvështrime filozofike dhe teknike', Tiranë: Botime Afroidit

[16] INSTAT, (2001), 'Migracioni në Shqipëri; Regjistrimi i Popullsisë dhe Banesave 2001' http://ëëë.instat.gov.al/media/3117/migracioni_n_shqiperi.pdf

[17] INSTAT, (2014) 'Migracioni në Shqipëri', Tiranë: Shtypshkronja Gentgrafik,

[18] Lami, R., (2013), 'Paqartësia e strukturimit të raporteve; Parti Politike-Ideologji', Tiranë: Universiteti i Tiranës, Fakulteti i Shkencave Sociale, Departamenti i Sociologjisë, Programi i të Doktoraturës http://ëëë.doktoratura.unitir.edu.al/ëp-content/uploads/2013/12/DoktoratureRoland-Lami-Fakulteti-i-Shkencave-Sociale-Departamenti-i-Sociologjise.pdf

[19] Mill J., S., (2005), 'Mbi Lirinë', përkthyer Gëzim Banushi dhe Luan Banushi, Tiranë: Shtëpia Botuese Julvin 2,

[20] Qwndra e Botimeve Zyrtare, [QBZ] (2010), 'Përmbledhëse Legjislacioni për Ndërtimet', botim i Qendrës së Botimeve Zyrtare, Tiranë https://qbz.gov.al/previeë/ba544cc3052a-4e95-8537-0c7c4547c1c8

[21] Qwndra e Botimeve Zyrtare, [QBZ] (2019), 'Përmbledhëse Legjislacioni për Urbanistikën', botim i Qendrës së Botimeve Zyrtare, Tiranë https://qbz.gov.al/preview/35686c1e-88ba-46c4-948e-30d619f28c98

[22] Spencer H., (2005), 'Njeriu Kundër shtetit', përkthim nga Bashkim Shehu, Tiranë: shtëpia botuese Dita 2000

[23] Top Channel Albania, [TCHA], (2016), 'Miratohet Plani Urbanistik për Tiranën', Tiranë https://ëëë.youtube.com/ëatch?v=6xSQG9JQET8

[24] Vizion Plus, [VP], (2016), 'Debate për Planin Urbanistik', Tiranë https://ëëë.youtube.com/ëatch?v=pm2dz0GGAMQ

[25] World Planners Congress, [WPC] (2006), 'Vancouver Declaration', Canada http://www.globalplannersnetëork.org/ëp-content/uploads/2017/08/ËPCdeclaration-2006-updated-June-2017.pdf 